\title{
5
}

\section{Transcending Boundaries in Legal Education: A Vehicle for Teaching Students to Think Critically}

\author{
Rosalie Jukier \\ McGill University
}

Legal education has traditionally been defined by many boundaries. Characterized by taxonomic structures and doctrinal categories, legal education is, for the most part, still seen as inextricably linked to a particular political geography and state normativity. The purpose of this paper is to demonstrate the pedagogical benefits of shattering established boundaries in legal education. It will assess how teaching from multiple perspectives in an integrated curriculum inculcates critical thinking skills in students, better enabling them to question assumptions, uncover hidden assumptions, and graduate as independent and innovative legal thinkers. Focusing on the 'transsystemic' McGill Law Program, this paper will discuss the rewards of engaging students in an intellectually pluralistic and tradition-neutral legal curriculum, one that eschews silos and borders and focuses on creating agile and creative minds in future jurists who will be able to confront contemporary legal issues holistically and with a critical perspective.

\section{Introduction}

$\mathrm{L}$ aw is a discipline that has been traditionally taught in a manner defined by many boundaries. The most obvious of such boundaries is related to jurisdiction or political geography. After all, at a very basic level, the law in force in a given jurisdiction (be it a country, state, province or municipality) is seen to be the one relevant and applicable to legal practice in that jurisdiction. The practice of law, in turn, is often referred to as amongst the most jurisdictionally restrictive of all professions in the sense that it is extremely difficult for lawyers educated and trained in one jurisdiction to move freely to practice law in others.

This traditional paradigm for law as a profession has had a tremendous influence on legal education, as the geographic boundaries that define law and the legal profession carry over into the academy. As a result, teaching the law in force in the particular jurisdiction in which a university is located is still the norm in most law schools, even those ranked amongst the best in the world. Moreover, it is still a prevalent view in many law schools that covering all relevant legal materials is a pedagogical problem. Professors often worry that there is not enough class time to teach all of the law in force in their own jurisdiction and therefore that they cannot afford to spend time teaching students the law in other jurisdictions. After all, it is argued, students will not be applying foreign law in the courts and in the law offices where they will 
practice. Indeed, beyond the particular context of legal education, general concerns about engaging with, or importing, foreign law are sometimes expressed. Justice Scalia of the United States Supreme Court, for instance, has gone so far as to refer to foreign law as "meaningless" and "dangerous dicta", stating that the highest Court in the U.S. "should not impose foreign moods, fads, or fashions on Americans" (Lawrence v. Texas, 2003, p. 598).

In 1999, the Faculty of Law at McGill University in Montréal, Quebec, Canada, moved away from this traditional conception of legal education as inextricably tied to a particular political geography or state normativity. Breaking the mold of legal nationalism in the classroom, McGill embarked on an ambitious and creative curricular innovation. Termed the 'transsystemic' law program, McGill's curriculum adopted a pedagogical approach based on the integrated study of multiple legal traditions (in particular, but not exclusively, the two major western legal traditions of civil and common law) as well as alternative sites of law (such as aboriginal and religious conceptions of law, and interdisciplinary approaches to legal issues) within blended courses.

From a pragmatic standpoint, the result was the creation of a program in which all students graduate with both civil law and common law degrees following three to four years of study. While students take compulsory and optional courses, in English or French, that cover the full range of subjects one finds in most law faculties, the difference is that at McGill, these courses are offered from an integrated and transsystemic perspective. Upon completion of the program, students leave McGill as 'cosmopolitan jurists' prepared to take on legal practice in today's evermore transnational world.

From an academic perspective, however, the result was the creation of a uniquely comparative, multi-systemic, pluralistic, and dialogic program of studying law. This program is personified by the integration of many voices, perspectives, and lenses without jurisdictional or systemic boundaries, highlighting a dialogue with, and learning from, other legal cultures and jurisdictions. Regardless of the precise ways in which students identify with one system or another, it is clear that they are constantly forced to ask difficult questions about the legal 'other' in the classroom. The effect of these changes has been a shift away from a professional model of legal education to a much more intellectual and conceptual one.

The purpose of this article is not, however, to explain, or even to laud the McGill Law Program. Many scholarly articles have already been written on the subject and, indeed, in 2005 an entire special edition of the McGill Law Journal was devoted to the topic of "Navigating the Transsystemic." Rather, the purpose is to demonstrate the transformative effect of this curricular innovation on course objectives and syllabi that has, in turn, altered our pedagogy in such a way as to enhance critical or flexible thinking skills in our students, highly prized skills in today's institutions of higher education (Tsui, 2006).

\section{Overview of the Integrated Law Program}

The new program required McGill law professors to rethink their legal pedagogy and to invent a "new mental map" to teach students traditional law courses (Arthurs, 2009, p. 635). There were no published coursepacks or textbooks to which they could immediately turn. Rather, a complete overhaul of course syllabi, together with teaching methods and modes of evaluation, was required. This is because one of the effects of teaching law in the traditional, jurisdictionally restrictive model is that the doctrinal and taxonomic structures inherent to a given legal tradition inevitably inform the organization of course syllabi. Before the implementation of the integrated program, many of McGill's courses followed this conventional model of legal education, emulating its divisions by organizing course material into established doctrinal categories. Taking the course on Contract Law as but one example, the common law Contract Law syllabus used to contain headings or divisions that included typical common law contract doctrines. Such headings would include 'Consideration', an esoteric and often problematic topic but something the common law tradition requires before a contract is recognized by the state and enforced in the courts. Another would be 'Undue Influence', a common law doctrine that enables a party to ask for relief from a contract into which he or she has entered due to an abuse of a relationship of trust and confidence that enabled the stronger party to take unfair advantage of the contracting party.

When, however, the Contracts course becomes blended or integrated and seeks to expose students to multiple perspectives on Contract Law, including the civil law's conception of contractual obligations, this established structure and traditional doctrinal division 
cannot be maintained for the simple reason that the civil law tradition does not recognize or give voice to concepts such as Consideration or Undue Influence. In fact, one quickly discovers that in most cases, the nomenclature and syntax of the different legal traditions do not match up. There are myriad examples of this lack of direct translation that exist from the perspective of both legal traditions. Just as Consideration means little in the civil law tradition, the civilian notions of 'Object,' 'Cause,' or 'Intensity of Obligations' are equally incomprehensible to the common law jurist.

This inability to match nomenclature has the fortunate effect of requiring course syllabi to be reorganized around broad themes, and course content to be reframed around larger questions rather than dogmatic doctrinal categories. As a result, instead of a course topic entitled 'Consideration,' an integrated contractual obligations course would have a heading such as 'Conditions of recognition of contract by the state,' or 'What else besides consent?' Rather than itemizing 'Undue Influence' as the doctrinal lesson of a particular class, the topic is taught as part of a larger question of how one achieves social control of contracts through judicial intervention for reasons of procedural and substantive unfairness. And instead of 'Intensity of Obligations,' a blended course syllabus would address the broader issue of defining breach. The net result is that lectures are framed by ideas and problems rather than traditional legal doctrinal topics.

\section{Linking Transsystemic Pedagogy to the Aspirations of Critical Thinking}

Critical thinking is said to encompass "higher order thinking processes that are reflected in the higher end of Bloom's taxonomy of educational objectives," characterized by the skills of analyzing, evaluating and creating, as opposed to remembering, understanding and applying (Krathwohl, 2002; Tsui, 2006). Often described as inculcating the ability to 'think outside the box,' critical thinking focuses on questioning underlying assumptions, uncovering hidden assumptions, and creating independent and innovative, rather than mechanistic, thinkers (Hinchey, 2008; James, Hughes, Clair, \& Cappa, 2010; Tsui, 2006; Weinstein, 1999). The pedagogical emphasis is shifted to the process, rather than the result, to the question, rather than the answer, to the 'how' and 'why,' rather than the 'what.'

The dialogic encounter between legal traditions taught in an integrated classroom lends itself to one of the central components of critical thinking, which involves questioning assumptions. Let us return to the notion of 'Consideration', a necessary component of a contract according to the common law. When students confront the fact that Consideration finds no voice in the civil law tradition, and learn that there are many different ways in which a legal system can 'bless' a contract with enforceability, they are better able to adopt a more critical perspective on this issue, making it more conducive for them to question the wisdom of the doctrine's very existence. Critical thinking involves challenging orthodoxy through "knowledgeable and skillful disobedience" (James et al., 2010, p. 287). By exposing students to multiple truths and a myriad of legal realities, the integrated transsystemic classroom provides the necessary atmosphere in which students can safely engage in such disobedience.

This pedagogical method also enhances students' abilities to uncover hidden assumptions, enabling them to explore the actual reasons and justifications underlying doctrines and legal outcomes. Here we may return to the example of 'Undue Influence' referenced above. Much more can be learned about this particular common law doctrinal response to contractual fairness in the transsystemic classroom than in the monosystemic one (restricted by common law orthodoxy), precisely because of the lack of direct equivalent comparators in the civil law tradition. By being forced to ask how the civil law manages without the benefit of this tool, particularly if it aspires to contractual fairness, students must confront the larger question of why the doctrine exists in the first place. Once they understand the deeper problems it was designed to address, they can then consider alternative legal approaches to those problems in another legal tradition. It is somewhat ironic that learning from another legal tradition, here the civil law, can actually allow one to gain more insight into, and a sophisticated understanding of, the legal tradition with which one started, in this case the common law. As one of my students stated after his first year of study in the transsystemic program, "If I would get stuck on a particularly thorny problem, it was very often helpful to switch gears and adopt the lens of another tradition in order to gain a point of entry." The valuable lesson here is that learning from the other often helps you 
learn more about yourself.

The greatest impact of this integrated pedagogy, however, derives from the need to abandon traditional legal categories altogether and teach from traditionneutral perspectives. The rejection of silos and boundaries is the key to training students to approach problems creatively and with open, questioning minds. If students are introduced to legal concepts without reference to rigid doctrinal categories, they will be less inclined to apply mechanistically what seem to be formulaic responses to legal issues. They will be more open to thinking about solutions to legal problems holistically, armed with a broader array of potential solutions. As Weinstein (1999) writes, "looking for new solutions that might stretch beyond the traditional boundaries" is what we want to inculcate in jurists who think critically and problem-solve creatively (p. 321).

This objective is, of course, easier said than done. Students have been taught from a young age to apply vertical thinking skills. Namely, they have been trained to find the appropriate category into which a problem falls and solve it using a set formula. Law school traditionally builds upon, and indeed amplifies, this traditional method of using vertical thinking skills: law students are trained to organize concepts and information into clear taxonomic structures. Learning to place what is sometimes described as "chaos with an index" into a coherent and logical organization is not a worthless aspiration (Glenn, 2010, p. 252). Law students certainly need to acquire the skills of organizing information appropriately. But they should not become prisoners of such categories. What McGill's law program seeks to do, therefore, is to transcend those categories and encourage students to imagine otherwise. It seeks to have students engage horizontal thinking skills as well as vertical ones, to pull threads throughout the entire course's materials (and indeed across different courses) in attempting to understand the bigger picture, and enable students to move between alternative systems of thought. To quote again from one of my students, "Constantly being reoriented towards the big picture questions rather than a linear approach gave us an instinct for flexible thinking."

\section{Conclusion}

When one frees the teaching of law from boundaries erected by doctrinal categorization emanating from discrete legal traditions, one shifts the focus from the rules in force in a particular jurisdiction to the fundamental structures, ideas, values, techniques, and processes of law. The aspiration of teaching law without state boundaries recognizes that the goal of legal education is not to create positivist robots, but rather to engage students in an intellectually pluralistic endeavour, developing their skills of imaginative insight and enabling them to see past traditional structures of reality. In this way, we can train cosmopolitan jurists who are better able to respond to the needs of our increasingly globalized world, but we can also inculcate critical thinking skills in our students so that they may become jurists who can deal with legal issues creatively, openly, and with a more complex and nuanced understanding of the contingent nature of law and justice.

\section{References}

Arthurs, H.W. (2009). Law and learning in an era of globalization. German Law Journal, 10(6), 629640.

Glenn, H.P. (2010). Legal traditions of the world (4th ed.). Oxford: Oxford University Press.

Hinchey, P.H. (2008). Becoming a critical educator: Defining a classroom identity, designing a critical pedagogy. New York: Peter Lang Publishing.

James, N., Hughes, C.H., \& Cappa, C. (2010). Conceptualising, developing and assessing critical thinking in law. Teaching in Higher Education, 15(3), 285-297.

Krathwohl, D.R. (2002). A revision of Bloom's Taxonomy: An overview. Theory Into Practice, 41(4), 212-218.

Lawrence v. Texas, 539 U.S. 558 (2003).

Tsui, L. (2006). Cultivating critical thinking: Insights from an elite liberal arts college. The Journal of General Education, 55(2), 200-227.

Weinstein, J. (1999). Coming of age: Recognizing the importance of interdisciplinary education in law practice. Washington Law Review, 74(2), 319-366. 


\section{Biography}

Rosalie Jukier is a professor in the Faculty of Law at McGill University and a member of the Paul André Crépeau Centre for Private and Comparative Law. She teaches and conducts research in the areas of comparative private law, Contracts and Remedies, Judicial Institutions and Civil Procedure, the intersection between human rights and private law, and legal pedagogy. 